\title{
THE CORRELATION BETWEEN ROAD NETWORK PERFORMANCE AND LAND PRICE: CASE STUDY SALATIGA CITY
}

\author{
Edwin Hidayat ${ }^{1}$, Iwan Rudiarto ${ }^{2}$, Walter de Vries ${ }^{3}$ \\ Received: August $16^{\text {th }} 2018$ \\ Accepted: November $23^{\text {rd }} 2018$
}

\begin{abstract}
Many aspects should be considered in planning a sustainable city, two of the aspects are transportation planning and population growth. These aspects have an important role in changing the urban structure and the occupancy rate of a city. Population growth always related to people activity, especially social and economic activities whereas road is the basic transportation to support the people activity. Moreover, increasing population means increasing the need of land for housing. This automatically triggered the land price fluctuation. The purpose of this paper is to examine the correlation of road network performance which represent accessibility and mobility toward land price. The method is started with gathering secondary data such as the road length, land price, and demographic data. Subsequently, statistical analysis is applied to understand the correlation among those data. The results showed that accessibility and mobility give positive correlation to the land price. However, in term of influence level, accessibility has a very weak influence on the land price. The mobility has a relatively significant influence towards land price.
\end{abstract}

Keywords: road network, mobility, accessibility, land price

\section{INTRODUCTION}

In general, a city is a place of opportunity compared to a village. There are two phenomena which represent this statement. On the one hand, the migration from rural to urban is absolutely linked with the economic aspect and the opportunity to get a better life (Tacoli, McGranahan, \& Satterthwaite, 2015 ) and (Yusoff, 216). As a result, many people move to the urban area as known as urbanization. In Indonesia, rural-urban migration is a dominant factor that causes high population growth in urban areas (Noveria, 2010).

On the second hand, there is a phenomenon called urban agglomeration which can be identified by commute trip (Wijaya, Kurniawati, \& Hutama, 2018) and (Liu, 2018). The definition of urban agglomeration is numerous and depend on the user perspective. In term of functional interconnectivity, agglomeration is mainly defined as an "urban field" and "urban functional economic zones" concepts. People commute from the peripheral regions to the city center whereas the maximum reachable areas should be within daily commutes (Fanga \& Yu, 2017). The urban field itself is a term for the place to live/housing area and urban functional economic zones is a term for a place to works whereas road network is the infrastructure to support the commute trip.

\footnotetext{
${ }^{1}$ Institute of Road Engineering, Ministry of Public Works and Housing

${ }^{2}$ Department of Urban and Regional Planning, Diponegoro University

${ }^{3}$ Department of Civil, Geo and Environmental Engineering, Technische Universitat Munchen
} 
Increasing population regarding the urbanization and increasing urban field related to agglomeration is equal to increasing the demand for the place to live, either housing or land for residential. Population growth led to the expansion of regional functions and increased demand for uncontrolled housing (Lestari \& Djumiko, 2017) and (Bhatta, 2010). Meanwhile, uncontrolled/sporadic development of land for housing resulted in fluctuation of land price, particularly which related to green area and public facilities (Han, Chen, Shu, Lin, \& Qiu, 2017) and (Bo, Zhicui, \& Ning, 2015). The up-and-down of land price can be predicted by using some approaches, the factor of property investment have been modeled (Sampathkumara, Santhi, \& Vanjinathan, 2015), the mobility and utility parameters (Hidayat, Rudiarto, Siegert, \& Vries, 2018) and the approach of using GIS-based model (Yang, et al., 2015).

Furthermore, development of housing area needs to be supported by several facilities for their daily needs such as the marketplace, education facility, and health facility whereas road network has an important role in connecting those facilities (Levashev, 2017) and (Giuffrida, Ignaccoloa, Inturria, Rofè, \& Calabrò, 2017). In addition, the road network has a function in facilitating the people activities and a good road infrastructure give a positive trend in support the economic activity (Ivanova \& Masarova, 2013) and (Meersman \& Nazemzadeh, 2017).

In Indonesia, transport infrastructure is dominated by road network. Accessibility and mobility are the approaches which can represent the road network in facilitating the people activities. Accessibility refers to the ease of reaching goods, services, activities, and destinations. While, mobility refers to physical movement, measured by trips, distance, and speed (Litman, 2017); and (Rau \& Vega, 2012). A similar statement about accessibility, it is a convenience measurement for road users to reach an activity center within a road-serviced area. While mobility is a measurement of the road service as measured by the convenience of each individual in traveling through the road to achieve its objectives (Iskandar, 2011).

Eventually, urbanization and agglomeration are created a high demand for land and uncontrolled housing area. In consequences, this demand has triggered a fluctuation in land price. Moreover, the sporadic development of housing land gives impact on the low roadservice. Road network cannot cover all housing area due to uncontrolled city development. Thus, the aim of this paper is to conceive the correlation between road network service which represent accessibility and mobility and the un-well-planned housing which represent the land price.

\section{Road Network Performance}

Previous studies have shown many indicators to measure the road network performance. Each indicator is developed depending on the perspective used that represent the functionality of the network from a specific aspect. Investigation of road performance based on the traffic engineering perspective such as the quality of traffic flow, geometric characteristics, and delay. Others address the road performance from the perspective the number of accidents or road safety. The impact of road activity, air pollution, and noise, for instance, is also proposed as an indicator for measure the road performance. Another indicator lies in the function of accessibility for the ease to reach destinations (TAC, 2006); (Fancello, Carta, \& Fadda, 2014); (Qin, He, \& Ni, 2014).

In this paper, the road network performance is calculated from the people activity perspective. Accessibility and mobility are the key indicators which have a connection with the land price functionality. There are many definitions of accessibility in the literature. However, most of the early studies are employed the function of location, distance and time spent (Balijepalli \& Oppong, 2014) and (Ford, Barr, Dawson, \& James, 2015). The 
accessibility is expressed as a delegation unit of road network based on (Oemar \& Daud, 2013) as follows:

Whereas:

$$
A C=\frac{R L}{B A}
$$

AC = accessibility $\left(\mathrm{km} / \mathrm{km}^{2}\right)$

$\mathrm{RL} \quad=$ road length $(\mathrm{km})$

BA $=$ broad area $\left(\mathrm{km}^{2}\right)$

In term of mobility, the formula is chosen as a representative unit of individual people in traveling through the road network. If the road network is poorly maintained, it will constrain mobility and the economic growth also social benefits will be interrupted (Burningham \& Stankevich, 2005). Mobility is important for the

individual trip because always influenced by population, either population size or population density (Pojani \& Stead, 2015). Mobility is expressed according to (Oemar \& Daud, 2013) as follows:

Whereas:

$$
M O=\frac{R L}{P O}
$$

$$
\begin{array}{ll}
\mathrm{AC} & =\text { accessibility }(\mathrm{km} / 1000 \mathrm{~km}) \\
\mathrm{RL} & =\text { road length }(\mathrm{km}) \\
\mathrm{PO} & =\text { population per } 1000 \text { person }(1000 \text { person })
\end{array}
$$

\section{Statistical Analysis}

In this case, the statistical analysis is employed to examine the correlation coefficient by using correlation analysis and influence level using regression analysis (linear and nonlinear) among some variables, namely land price, accessibility, and mobility.

The correlation analysis is a term used to denote the association or relationship between two (or more) quantitative variables. This analysis is fundamentally based on the assumption of a straight-line (linear) relationship between the quantitative variables (Gogtay \& Thatte, 2017). Correlation coefficients do not give information about whether one variable moves in response to another. There is no attempt to establish the dependent variable and the other as an independent variable. The magnitude of the correlation coefficient can be known based on the dispersion of the meeting points between two variables such as $\mathrm{X}$ and $Y$. If the points are in one line, then the correlation coefficient $=1$ or -1 meaning the correlation is strong. When the points form a circle, the correlation coefficient $=0$ meaning the correlation is weak.

The Pearson coefficient or well knew with Product-Moment correlation is applied to this case. The definition of this analysis is the ratio of the covariance of two variables representing a set of numerical data, normalized to the square root of their variances (Hall, 2015). The formula for this functions as follows:

Whereas:

$$
r=\frac{\sum x y}{\sqrt{\left(\sum x^{2} y^{2}\right.}}
$$

$$
\begin{array}{ll}
\mathrm{r} & =\text { correlation between variable } \mathrm{x} \text { dan } \mathrm{y} \\
\mathrm{x} & =\left(\mathrm{x}_{\mathrm{i}}-\mathrm{X}\right) \\
\mathrm{y} & =\left(\mathrm{y}_{\mathrm{i}}-\mathrm{Y}\right)
\end{array}
$$


Afterwards, the significancy of correlation coefficient needs to be check by using ttest. The result of t-test is compared with the t-tabel. For multiple correlation, the formula as follows:

Whereas :

$$
R_{y \cdot x_{1} x_{2}}=\sqrt{\frac{r_{y x_{1}}^{2}+r^{2}{ }_{y x_{2}}-2 r_{y x_{1}} r_{y x_{2}} r_{x_{1} x_{2}}}{1-r^{2} x_{1} x_{2}}}
$$

Ry. $\mathrm{x}_{1} \mathrm{x}_{2}=$ multivariable correlation between variables $\mathrm{x}_{1}$ and $\mathrm{x}_{2}$ together with variable $\mathrm{y}$

ryx $_{1}=$ Product-Moment correlation between $\mathrm{x}_{1}$ and $\mathrm{y}$

$\mathrm{ryx}_{2} \quad=$ Product-Moment correlation between $\mathrm{x}_{2}$ and $\mathrm{y}$

$\mathrm{rx}_{1} \mathrm{x}_{2}=$ Product-Moment correlation between $\mathrm{x}_{1}$ and $\mathrm{x}_{2}$

Subsequently, the significance of multivariable correlation is checked by using f-test. Then, the f-test value is compared with the f-table.

The regression analysis is divided into linear and non-linear. Regression measures how much a variable affects other variables, so it can be used to forecast the value of a variable based on other variables. The variable to be explained (land price) is called the dependent (response) variable, and variables that explain it (accessibility, mobility) are called independent variables or predictor variables. Regression analysis employs a model that describes the relationships between the dependent variables and the independent variables in a simplified mathematical form (Schneider, Hommel, \& Blettner, 2010). The formula for a linear multivariable regression as follows:

Whereas:

$$
\mathrm{Y}=\mathrm{a}+\mathrm{b} 1 \times \mathrm{X} 1+\mathrm{b} 2 \times \mathrm{X} 2+\ldots+\mathrm{bn} \times \mathrm{Xn}
$$

$\mathrm{Y} \quad=$ dependent variable

$\mathrm{Xi} \quad=$ independent variables

a $\quad=$ constant $(\mathrm{y}$-intersect)

$\mathrm{b} 1=$ regression coefficient of the variable $\mathrm{X}$

Meanwhile, if the scatterplot of data does not follow a straight line, but follows a certain curve form. Then, a suitable analysis to explain the relationship between $\mathrm{X}$ and $\mathrm{Y}$ is a non-linear regression. The non-linear regression model is a generalization of the linear regression model in which the conditional mean of the response variable is not a linear function of the parameters (Fox \& Weisberg, 2010). This analysis can give a better accuracy than linear regression because when estimating the model used algorithm iteration. There are several non-linear regressions namely, polynomial, exponential, reciprocal and others.

The regression analysis is interpreted by looking at the coefficient of determination $\left(\mathrm{R}^{2}\right)$. It reflects the fraction of variation in the Y-values that is explained by the regression line (Schneider, Hommel, \& Blettner, 2010). $\mathrm{R}^{2}$ provides information about the strength and direction of a relationship between two continuous variables. If $\mathrm{R}^{2}= \pm 1$ means perfect linear and monotone relationship. The closer $\mathrm{R}^{2}$ to 1 or -1 , the stronger the relationship. If $\mathrm{R}^{2}=0$ means no linear or monotone relationship.

\section{Overview of Road Network and Land Market in Salatiga}

Salatiga city is divided into 4 districts and 23 subdistricts. Total population in 2016 is 186.420 people with the total area of 56.781 square kilometers (BPS, Salatiga Municipality in Figures, 2017). In general, the road network system in Indonesia is classified into 5 categories, namely, toll road or freeway, artery road for connecting between national activity center, collector road for connecting between districts (urban road), the local road for 
connecting between sub-districts, and neighborhood road usually in the settlement area (Indonesia, 2004). In Salatiga, the arterial road as much as $11.795 \mathrm{~km}$, the collector road is $112.955 \mathrm{~km}$, the local road is $210.250 \mathrm{~km}$ and around $80,000 \mathrm{~km}$ of the neighborhood roads. Regarding the pavement type, from 415,000 km in total length of roads in Salatiga, 307.965 $\mathrm{km}$ are asphalt roads, and $107.035 \mathrm{~km}$ is soil road (BPS, Salatiga City in Figure, 2016). Neighborhood roads mainly have non-asphalt pavement due to lower vehicle loads, the pavement usually compacted soil or concrete block. Figure 1 presents the road network in Salatiga City as well as the land price.

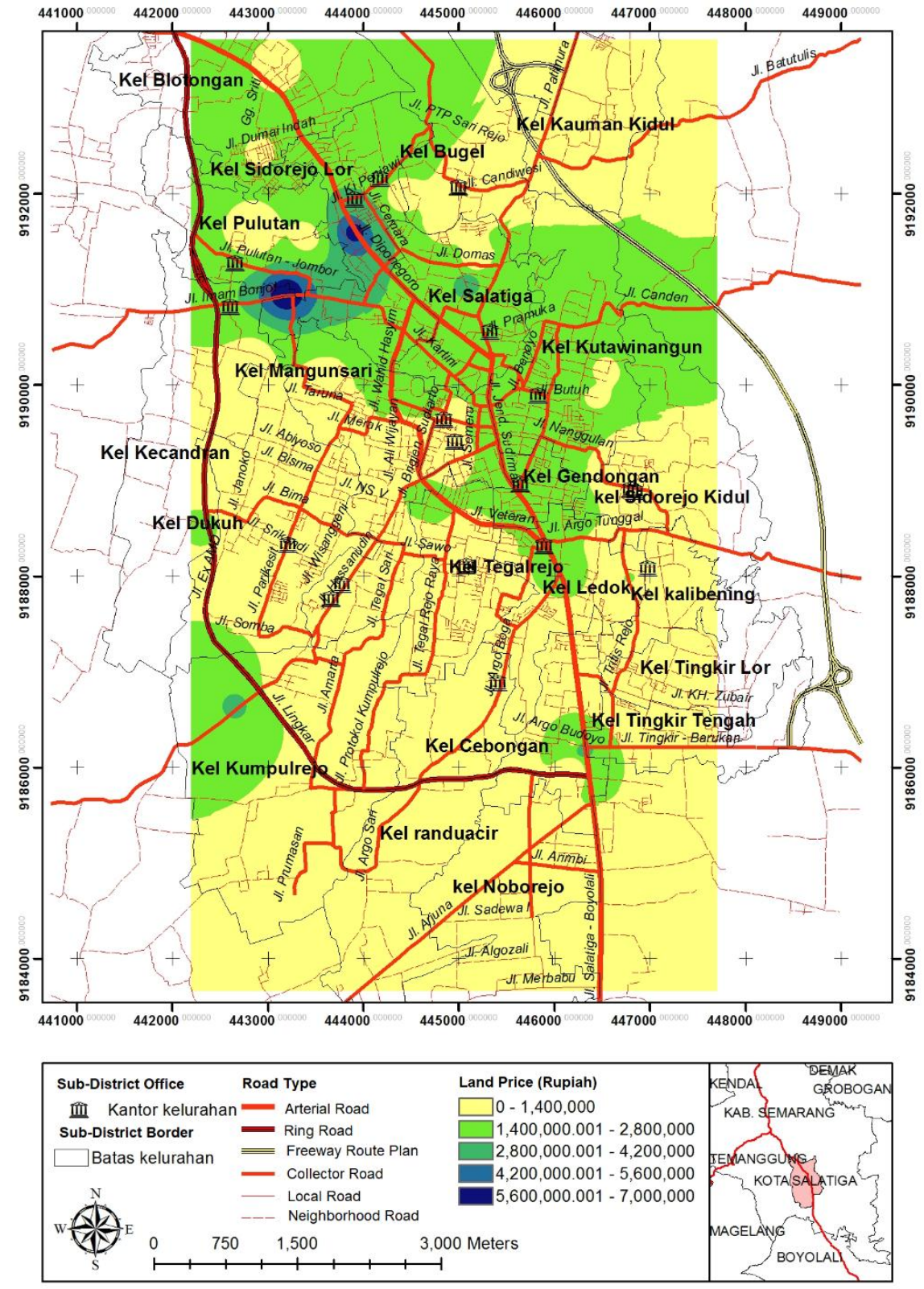

Source: (Hidayat E. , 2017)

Figure 1. Road Network and Land Price in Salatiga 
Meanwhile, the land transaction in Salatiga is driven particularly for housing. The new development of housing triggers the need for land. Compare to previous years, the land transaction fluctuates every year along with the permit for construction of new buildings. The land market profile in 2016 as much as 291 building license is issued and 1506 land transaction (buy and sell). Moreover, the land tenure system in Indonesia consists of Hak Milik or the highest level equal with freehold tenure, Hak Guna Bangunan (HGB) means right for the building only, Hak Pakai or a right to use only, and Hak Tanggungan or a guaranteed right, Wakaf means land grant for religious purposes. In sequence, the total issued in 2016 for each tenure are 2252, 0, 226, 1433 and 13 land titles (BPS, Salatiga Municipality in Figures, 2017).

\section{METHOD}

This study is adopted a quantitative approach. The methodology is comprised of several steps as follows:

a. The first step is arranged the research design

b. Follow the second step that is gathered secondary data. The road length is generated from GIS data came from the agency for planning and development (Bappeda). The land price is gathered from the property agent in Salatiga, this price consists of offer price from the seller and an additional fee for the agent. Demographic data is collected from the central statistical bureau (BPS).

c. Prior to analysis, data preparation is required. The road length consists of neighborhood road, local road, collector road and the arterial road. This data is a breakdown of the road network in the case study location using GIS approach. The land price used in this analysis is comprised of 3 land prices per subdistrict, then to be average to represent the land price per subdistrict. Demographic data used for measure accessibility is total square area per subdistrict and total population to measure the mobility.

d. Next step is the data calculation, the accessibility and mobility are measured by using the equation above.

e. Implementation of statistical analysis is served to reveal the correlation coefficient. Then, linear and non-linear regression analysis is executed to understand the influence level.

f. The last step is the interpretation of the analysis result.

\section{RESULT AND DISCUSSION} as follows:

After following the methodology, the result of the correlation analysis can be seen in table 1

Table 1. Result of Correlation Analysis

\begin{tabular}{cllll}
\hline No & Variables & $\begin{array}{l}\text { Correlation } \\
\text { Coefficient }\end{array}$ & t-test estimated & 95\% t-test table \\
\hline 1 & Accessibility \& Land Price & 0.81 & 6.32 & 2.83 \\
2 & Mobility \& Land Price & 0.69 & 4.32 & 2,83 \\
& & & & \\
\hline
\end{tabular}

Source: Analysis, 2018

Based on table 1, the correlation coefficients for accessibility and land price as well as for mobility and land price resulted in a strong correlation between those variables because the value is $>0.6$. The correlation coefficient also has a positive value, it means much better the accessibility, the higher land price. Same meaning also for mobility and land price. 
Subsequently, the correlation between those variables is significant based on the t-test estimated which has a higher value compared to t-test table.

Regarding multivariable correlation analysis, the correlation coefficient for accessibility, mobility, and land price can be seen in table 2 as follows:

Table 2. Result of Multivariable Correlation Analysis

\begin{tabular}{cllll}
\hline No & Variables & $\begin{array}{l}\text { Correlation } \\
\text { Coefficient }\end{array}$ & f-test estimated & 95\% f-test table \\
\hline 1 & Accessibility, Mobility, Land Price & 0.81 & 19.32 & 3.49 \\
\hline
\end{tabular}

Source: Analysis, 2018

Table 2 presents the multivariable correlation among accessibility, mobility and land price. The results show that the correlation coefficient is strong because of $0.81>0.6$. The result shows that these three variables have a positive correlation. Then, comparison of $\mathrm{f}$ test estimated and f-test table also showed the significant correlation among those variables because the f-test estimated is higher to the f-test table.

Moreover, the influence level of accessibility, mobility and land price is measured by using regression analysis, either linear or non-linear. The causality between variables of accessibility and land price can be seen in figure 2 as follows:

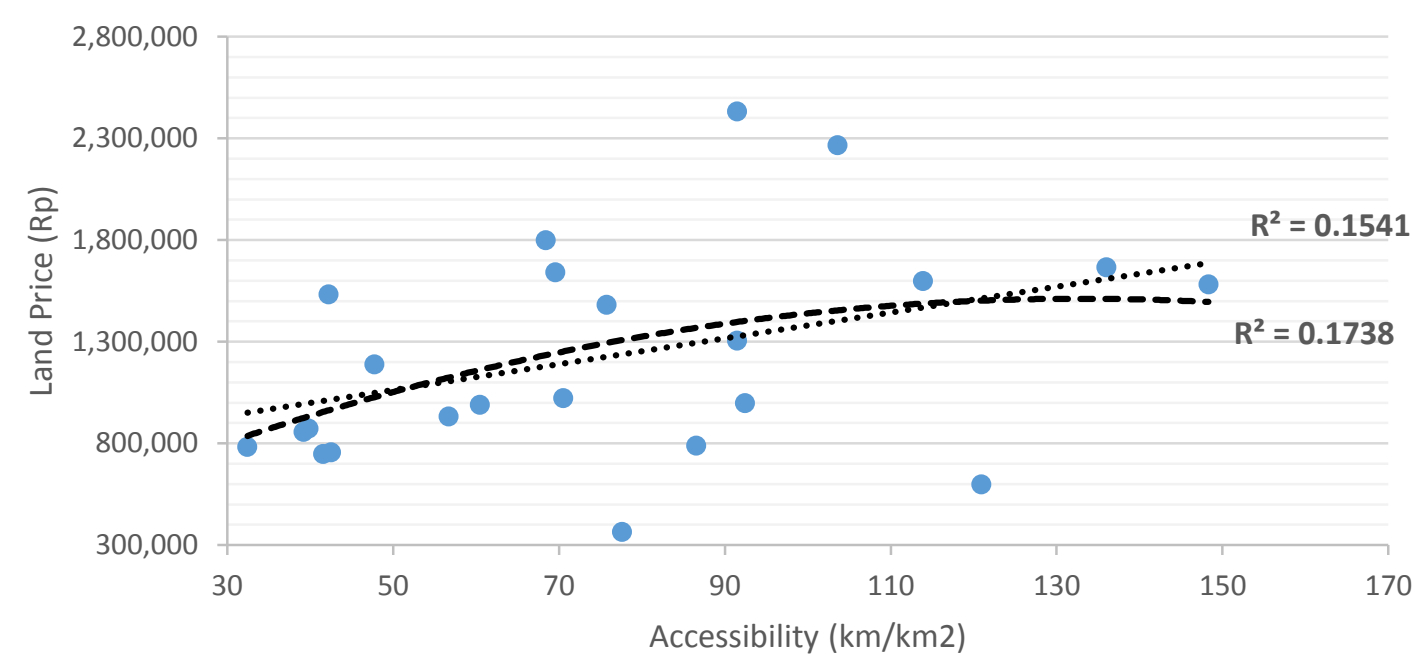

Source: Analysis, 2018

Figure 2. Regression Analysis For Accessibility and Land Price

Figure 2 depicts information about the effect of accessibility on land price. This graph shows dotted-line which represent the linear regression and stripped-line which represent the non-linear regression (polynomial). Both lines resulted in a small number of $\mathrm{R}^{2}$ or very weak relationship because the value is $<0.5$. It means the accessibility cannot be used for predicting the land price due to small response between independent and dependent variable.

The cause-and-effect relationship between mobility and land price can be seen in figure 3 as follow: 


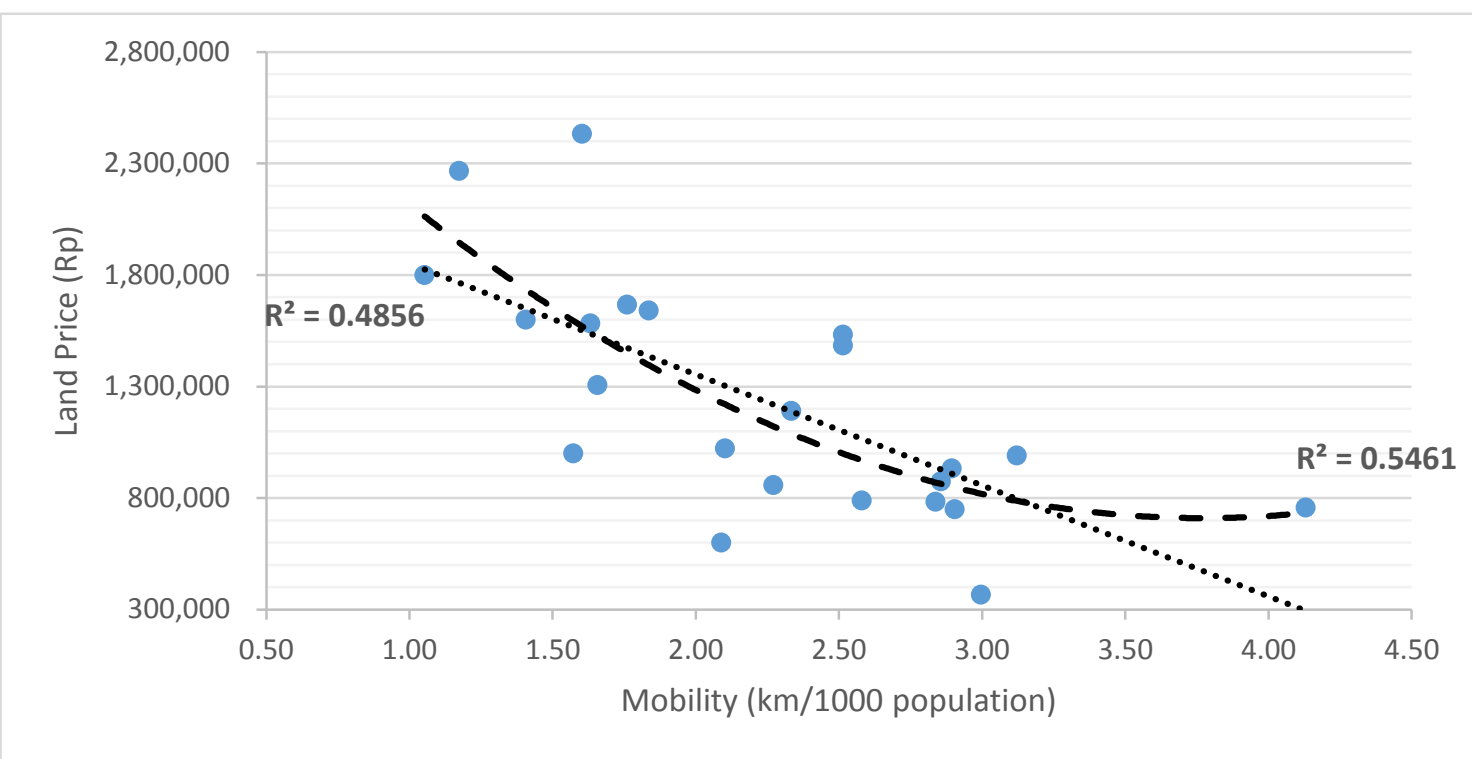

Source: Analysis, 2018

Figure 3. Regression Analysis For Mobility and Land Price

Based on figure 3, it can be seen that the line-graph shows the causality relationship between mobility and land price. However, the coefficient determination or $\mathrm{R}^{2}$ has resulted in insignificant value for linear regression analysis which is $0.48<0.5$. The non-linear regression used here is a polynomial and generated a relatively better $\mathrm{R}^{2}$ value, namely $0.54>0.5$. This value means as much as $54 \%$ of the land price is influenced by mobility in the case study location. Thus, there are $46 \%$ is influenced by the other factors.

\section{CONCLUSION}

Under examination using statistical analysis, the linkages between road network performance and land price can be elaborated. The analysis consists of two approaches, namely correlation and regression. The road network performances are accessibility and mobility. The land price is a dynamic effect of uncontrolled housing development.

The correlation between accessibility and land price have resulted in a positive and strong correlation coefficient. The comparison of t-test estimated and t-test table has revealed that this correlation also significant. Meanwhile, the correlation between mobility and land price has also resulted in a positive and strong correlation coefficient. The t-test estimated and t-test table also has been compared and indicated a significant correlation. In addition, the multivariable correlation has been executed and resulting in a positive and strong correlation among accessibility, mobility and land price. The comparison of f-test estimated and f-test table is indicated a significant variable. Overall, the quantitative data of accessibility, mobility, and land price are produced a fundamental connection.

The influence level of accessibility, mobility, and land price is determined using regression analysis. This analysis consists of linear regression and non-linear regression. The causal effect of accessibility on land price has a very weak influence for both linear and nonlinear analysis. The accessibility cannot be used for forecasting the land price due to small response between those variables. A much better result has been showed by the cause-andeffect relationship between mobility and land price. The linear regression for mobility and land price have a higher value compare to accessibility and land price. Moreover, the nonlinear regression (polynomial) has generated a relatively better coefficient determination. It 
is denoted that the land price is influenced by the mobility, but this influence not working for accessibility.

Finally, the road network performance can be concluded has a strong correlation with the land price. However, the road network performance is not good enough for forecasting the land price due to small response between those variables. As a collateral effect, the road network performance has a limited influence towards uncontrolled housing development.

\section{ACKNOWLEDGMENT}

This research is supported by the Ministry of Public Works and Housing - Indonesia as a part of the scholarship for an M.Sc program at Technische Universitat Munchen.

\section{REFERENCES}

Balijepalli, C., \& Oppong, O. (2014). Measuring vulnerability of road network considering the extent of serviceability of critical road links in urban areas . Journal of Transport Geography, 39, 145-155.

Bhatta, B. (2010). Analysis of Urban Growth and Sprawl from Remote Sensing Data. Advances in Geographic Information Science.

Bo, X., Zhicui, L., \& Ning, X. (2015). The Interactive Influence of Urbanization, land Price and Industrial Structure Adjustment - the Empirical Analysis from China. Journal of Business \& Economic Policy Vol. 2, No. 3, 81-91.

BPS. (2016). Salatiga City in Figure. Salatiga: Badan Pusat Statistik Kota Salatiga.

BPS. (2017). Salatiga Municipality in Figures. Kota Salatiga: Badan Pusat Statistik .

Burningham, S., \& Stankevich, N. (2005). Why road maintenance is important and how to get it done . WASHINGTON, DC : THE WORLD BANK.

Fancello, G., Carta, M., \& Fadda, P. (2014). A modeling tool for measuring the performance of urban road networks. Procedia - Social and Behavioral Sciences 111.

Fanga, C., \& Yu, D. (2017). Urban agglomeration: An evolving concept of an emerging phenomenon. Landscape and Urban Planning 162, 126-136.

Ford, A. C., Barr, S. L., Dawson, R. J., \& James, P. (2015). Transport Accessibility Analysis Using GIS: Assessing Sustainable Transport in London. ISPRS Int. Journal Geo-Information 4, 124-149.

Fox, J., \& Weisberg, S. (2010). Nonlinear Regression and Nonlinear Least Squares in R. In J. Fox, \& S. Weisberg, An R Companion to Applied Regression, Second Edition. Sage Publications.

Giuffrida, N., Ignaccoloa, M., Inturria, G., Rofè, Y., \& Calabrò, G. (2017). Investigating the Correlation between Transportation Social Need and Accessibility: the Case of Catania. Transportation Research Procedia 27, 816-823.

Gogtay, N., \& Thatte, U. (2017). Principles of Correlation Analysis. Journal of The Association of Physicians of India, Vol. 65, March .

Hall, G. (2015). Pearson's correlation coefficient. London: Imperial College London.

Han, H., C. H., Shu, X., Lin, L., \& Qiu, D. (2017). The Effects of Greenbelt Policies on Land Development: Evidence from the Deregulation of the Greenbelt in the Seoul Metropolitan Area. Sustainability MDPI, 9.

Hidayat, E. (2017). Modelling the Dynamics Interrelation between Mobility, Utility and Land Asking Price. Munchen: Master Thesis, Department of Civil, Geo and Environmental Engineering, Technische Universitat Munchen.

Hidayat, E., Rudiarto, I., Siegert, F., \& Vries, W. D. (2018). Modeling the Dynamic Interrelations between Mobility, Utility, and Land Asking Price. IOP Conf. Series: Earth and Environmental Science 123 (2018). IOP Publishing.

Indonesia. (2004). Indonesian Law number 38 year 2004 about road. Jakarta: Ministry of State Secretariate.

Iskandar, H. (2011). Minimum Service Standard Analysis for Non Toll Roads. Jalan Jembatan Journal Vol 28, No 1 .

Ivanova, E., \& Masarova, J. (2013). Importance Of Road Infrastructure In The Economic Development And Competitiveness. ECONOMICS AND MANAGEMENT 18 (2). 
Lestari, D. S., \& Djumiko. (2017). Perkembangan Perumahan Dan Permukiman Sebagai Penentu Arah Dan Bentuk Kebutuhan Permukiman Di Pinggiran Kota. e-Jurnal Teknik Sipil Dan Arsitektur Fakultas Teknik UTP Surakarta Vol. 21 No 25, Juli .

Levashev, A. (2017). Application of Geoinformation Technologies for the Transportation Demand Estimation. Transportation Research Procedia 20, $406-411$.

Litman, T. (2017). Evaluating Accessibility for Transport Planning. Victoria Transport Policy Institute.

Liu, K. (2018). Spatiotemporal Analysis of Human Mobility in Manila Metropolitan Area with PersonTrip Data. Urban Sci. 2, 3.

Meersman, H., \& Nazemzadeh, M. (2017). The contribution of transport infrastructure to economic activity: The case of Belgium. Case Studies on Transport Policy Volume 5, Issue 2, June , 316-324.

Noveria, M. (2010). Fenomena Urbanisasi Dan Kebijakan Penyediaan Perumahan Dan Permukiman Di Perkotaan Indonesia. Masyarakt Indonesia EDISI XXXVI / NO.2 / 2010 , 103-1024.

Oemar, \& Daud, J. (2013). Study Of Road Network Performance In Regional District of Labuhan Batu. Jurnal Teknik Sipil Usu Vol 2, No 1.

Pojani, D., \& Stead, D. ( 2015). Sustainable Urban Transport in the Developing World: Beyond Megacities. Sustainability, 7.

Qin, J., He, Y., \& Ni, L. (2014). Quantitative Efficiency Evaluation Method for Transportation Networks. Sustainability, 6.

Rau, H., \& Vega, A. (2012). Spatial (Im)mobility and Accessibility in Ireland: Implications for Transport Policy. Growth And Change 43 (4), 667-697.

Sampathkumara, V., Santhi, H., \& Vanjinathan, J. (2015). Forecasting the land price using statistical and neural network software. Procedia Computer Science 57 (2015) 112 - 121, 112-121.

Schneider, A., Hommel, G., \& Blettner, M. (2010). Linear Regression Analysis. Deutsches Ärzteblatt International 107 (44), 776-782.

TAC. (2006). Performance Measures for Road Networks: A Survey of Canadian Use . Transport Canada .

Tacoli, C., McGranahan, G., \& Satterthwaite, D. (2015 ). Urbanization, Rural-urban Migration and Urban Poverty. London: International Organization for Migration (IOM).

Wijaya, H. B., Kurniawati, H., \& Hutama, S. (2018). Industrialization Impact on Worker Mobility and Land Use in Peri Urban Area (Case study of Semarang District, Indonesia). IOP Conf. Series: Earth and Environmental Science 123. Solo, Central Java.

Yang, Y., Sun, Y., Li, S., S. Z., Wang, K., Hou, H., \& Xu, S. (2015). A GIS-Based Web Approach for Serving Land Price Information. International Journal of Geo-Information 4, 2078-2093.

Yusoff, N. B. (216). Urbanization In Sustainable Economics Growth Of Peninsular Malaysia Northern Economic Corridor. South East Asia Journal of Contemporary Business, Economics and Law, Vol. 10, Issue 3. 